\title{
Penerapan Klausul Standar Baku dalam Perjanjian Kredit Bank
}

\author{
Suyitno \\ Budi Agus Riswandi
}

\begin{abstract}
The form of a standard contract is much applied in the practice of a bank credit agreement. It is aimed at ensuring loan credited by a debtor. Thus, this loan is essentially fund belonging to customers. Consequently, a bank, on the one hand, is obliged to pay attention to the debtor's vested interest. As a result, the aspect of a balance in an agreement is met if the debtor's vested interest is included in the agreement.
\end{abstract}

\section{Pendahuluan}

Bank sebagai lembaga keuangan mempunyai fungsi intermediari yakni, menghimpun dana sekaligus menyalurkannya kepada pihak-pihak yang memerlukan dana tersebut berupa kredit bank mempunyai arti yang sangat strategis dalam mendorong kegiatan bisnis.

Kenyataannya bank dalam menjalankan fungsi menyalurkan kredit acapkali mempergunakan perjanjian kredit bank dalam bentuk perjanjian baku (standard contract). Perjanjian baku biasanya memuat klausulklausul yang sifatnya sepihak, dalam hal ini hanya dari pihak bank saja. Dalam arti kata debitur tidak terlibat langsung dalam menentukan substansi atau materi dari perjanjian itu. Debitur dihadapkan kepada apakah ia menerima atau menolak perjanjian tersebut (take it or leave it).
Dari kondisi demikian sangat riskan bagi pihak debitur kepentingan-kepentingan mereka tidak diperhatikan oleh pihak bank. Di sisi lain bank menerapkan perjanjian baku didasarkan pada upaya pengamanan dana yang dimiliki bank, yang pada dasarnya merupakan dana nasabah. Dari dua pandangan yang berbeda ini ada sebuah pertanyaan yang mendasar bagaimana menerapkan klausul baku dalam perjanjian kredit bank, sehingga kedua kepentingan tersebut dapat diakomodir.

\section{Prinsip Pemberian Kredit Perbankan di Indonesia}

Istilah kredit berasal dari bahasa. Yunani, yaitu Credere yang berarti kepercayaan. Dengan demikian, dasar pemberian kredit adalah kepercayaan dan keyakinan bahwa 
debitur akan melunasi hutangnya sesuai dengan yang diperjanjikan atau tepat waktu. ${ }^{1}$ Atas dasar ini, maka hakekat dari pemberian kredit adalah pemberian kepercayaan kepada debitur. Pengertian kredit adalah suatu pemberian prestasi oleh suatu pihak kepada pihak lain dan prestasi itu tersebut dikembalikan lagi pada suatu masa tertentu yang akan datang disertai dengan suatu kontra prestasi berupa bunga. ${ }^{2}$

Pasal 1 angka 12 UU No. 7 Tahun 1992 tentang Perbankan Jo UU No... ${ }^{3}$ yang menyatakan Kredit ialah penyediaan uang atau tagihan yang dapat dipersamakan dengan itu, berdasarkan persetujuan atau kesepakatan pinjam meminjam antara bank dengan pihak lain yang mewajibkan pihak peminjam untuk melunasi hutangnya setelah jangka waktu tertentu dengan jumlah bunga, imbalan atau pembagian hasil keuntungan.

Kredit dalam arti umum meliputi commercial loan dan consumer's loan. Commercialloan merupakan kredit yang diberikan kepada seseorang atau badan usaha, sehingga kredit ini mampu memperbaiki atau mengembangkan kinerja (performance) usaha debitur, bahkan jika mungkin dapat menciptakan backward and forward linkage dan seterusnya dapat membawa efek berganda yang bersifat positif (multiplier effect). Consumer's loan merupakan kredit yang diberikan bukan untuk kegiatan usaha yang produktif, tetapi untuk penggunaan yang bersifat konsumtif, namun mampu meningkatkan taraf hidup dan memperkuat daya beli si peminjam, yang secara tidak langsung mendorong pertumbuhan dan perkembangan sektor riil. ${ }^{4}$

Di dunia perbankan pemberian kredit baru dapat dilakukan apabila telah memenuhi prinsip-prinsip pemberian kredit. Prinsip ini sebagai upaya dari pihak bank agar pemberian kredit kepada debitur dapat diminimalisasi risikonya, sekaligus sebagai alat ukur layak tidaknya permohonan kredit dari kreditur dikabulkan. Prinsip yang dimaksudkan meliputi prinsip 5C, 5P, dan 3R.

Penilaian permohonan kredit yang berhubungan dengan prinsip-prinsip $5 \mathrm{C}$, meliputi:

\section{a. Character (watak)}

Seorang debitur yang meminta kredit akan diteliti characternya, meliputi kebiasaan-kebiasaan, sifat-sifat pribadi, cara hidup (stile of living), keadaan keluarganya (anak dan istri), hobi dan kedudukan sosial, Ini merupakan ukuran willingness to pay yaitu kemauan untuk membayar. ${ }^{5}$

Watak yang tertuang di atas, dalam kenyataannya sangat sulit untuk dianalisis sebab sifatnya sangat abstrak. Terkadang

'Widjanarto. 1998. Aspek Hukum Pemberian Kredit Perbankan. Jakarta: InfoBank. HIm. 4.

${ }^{2}$ Muchdarsah Sinunga. 1983. Dasar-dasar dan Teknik Managemen Kredit. Jakarta: Bina Aksara. HIm. 12. 3Selanjutnya UU No. 7 Tahun 1992 tentang Perbankan dalam tulisan ini disebut dengan UU Perbankan

${ }^{4}$ Moh. Tjoekam. 1999. Perkreditan Bisnis Inti Bank Komersial Konsep Teknik dan Kasus.Jakarta: Gramedia Pustaka Utama. HIm.10-11.

${ }^{5}$ Muchdarsah Sinungan. 1992. Managemen Dana Bank. Jakarta: Bina Aksara. HIm. 242. 
debitur dalam memberikan informasi atau data-data kepada pihak bank tidak sesuai dengan data riilnya.Untuk mengimbangi data yang dișampaikan olẹh debitur; maka para pengelola kredit (account officer) harus mempunyai keterampilan psikologi praktis untuk dapat mengenali watak atau karakter dari calon debiturnya. ${ }^{6}$ Upaya lainnya yang dapat dilakukan biasanya bank juga dapat mencari sumber pengetahuan lain tentang karakter debitur. Sumber itu dapat dicari dari informasi pesaing, customer, supplier, instansi terkait, dan lain sebagainya.

b. Capacity (kemampuan) Bank perlu mengetahui kemampuan debitur dalam mengelola usaha, apakah nasabah mempunyai pengetahuan yang cukup di bidang usaha tersebut, apakah debitur tersebut berpengalaman dalam mengelola perusahaan dan sebagainya. Seperti kemampuan pemimpin perusahaan juga diperhatikan oleh bank. Seperti kemampuan pemimpin, menguasai bidang usaha, kesungguhan mengelola dan menguntungkan.?

c. Capital (modal)

Capital adalah modal sendiri yang dimiliki oleh calon debitur, besar capital ini dapat dilihat dari neraca pembukuan, yaitu berupa himpunan owner quity laba yang ditahan, cadangan dan lain-lain. ${ }^{8}$

d. Collateral (jaminan)

Collateral adalah barang jaminan yang diserahkan oleh debitur sebagai jaminan atas kredit yang diterimanya dari bank. ${ }^{9}$

e. Condition of Economic (kondisi ekonomi) Condition of Economic yaitu situasi dan kondisi ekonomi politik, sosial, budaya yang dapat mempengaruhi keadaan perekonomian atau keuangan pada suatu saat dan dapat mempengaruhi kelancaran usaha dari perusahaan/debitur yang menerima kredit. ${ }^{10}$

Bank melakukan penilaian kredit yang berkaitan dengan prinsip-prinsip $5 \mathrm{P}$, yaitu meliputi:11 :

"Widjanarto. "Kajian Legal dalam Añalisa dan Proses Kredit Komersial serta Solusi Hukum Menghadapi Kredit Bermasalah." Dalam Solusi Hukum dalam Menyelesaikan Kredit Bermasalah. Jakarta: InfoBank. HIm. 36.

'Gatot Supramono. 1997. Perbankan dan Masalah Kredit (Suatu Tinjauan Yuridis). Jakarta: Djambatan. Hlm. 2. Bandingkan dengan pendapatnya Muchdarsyah Sinungan yang menyatakan bahwa Capacity merupakan ukuran ability to pay yaitu kemampuan membayar. Penelitian kemampuan ini berdasarkan pengalaman dalam bisnis yang dihubungkan dengan pendidikannya, pengalaman bisnisnya dalam menyesuaikan diri dengan kondisi perekonomian dan ketentuan pemerintah. Muchdarsyah Sinungan. Managemen...Loc.Cit. HIm. 243.

"Widjanarto. "Kajian Legal...". Loc. Cit.HIm.39.

${ }^{9} /$ bid.

iolbid.

"Hadiwidjaja dan Rivai Wirasasmita. 1991. Analisis Kredit (Dilengkapi Telaah Khusus). Jakarta: Pionir Jaya. HIm. 9. 
a. Party atau calon debitur peminjam dana

b. Payment merupakan sumber pembayaran

c. Profitability adalah kemampuan untuk memperoleh laba

d. Purpose tujuan dalam menggunakan kredit

e. Protection atau perlindungan supaya tidak terjadi hal yang tidak diinginkan di kemudian hari.

Analisis terhadap prinsip $3 R_{1}$ meliputi: ${ }^{12}$

a. Return artinya hasil yang akan diperoleh dalam mengucurkan kredit.

b. Repayment maksudnya pembayaran kembali kredit yang sudah diberikan kepada debitur.

c. Risk bearing ability yaitu kemampuan untuk menanggung resiko dari bisnisnya. Hal ini berupa asuransi dan jaminan.

Di samping pemenuhan syarat $5 \mathrm{C}, 5 \mathrm{P}$, dan 3R menurut Munir Fuady peluncuran kredit oleh suatu bank seharusnya berpegang kepada prinsip pemberian kredit lainnya yaitu; prinsip kepercayaan dan kehati-hatian. ${ }^{13}$
Penerapan Klausul Standar Baku dalam Perjanjian Kredit Bank

Pengertian perjanjian dalam Pasal 1313 KUHPerdata dikatakan sebagai suatu perbuatan yang terjadi antara satu orang atau lebih mengikatkan dirinya terhadap orang lain. Namun demikian, definisi ini oleh para pakar hukum dianggap sifatnya sepihak dan terlalu luas. ${ }^{14}$ Sehingga dengan alasan ini J. Satrio Mengusulkan agar bunyi pasal tersebut diubah menjadi: atau di mana kedua belah pihak saling mengikatkan diri. ${ }^{15}$

Selanjutnya untuk sahnya suatu perjanjian Pasal 1320 KUHPerdata mensyaratkan émpat unsur:

1. Sepakat bagi mereka yang mengikatkan dirinya;

2. Cakap untuk membuat suatu perikatan;

3. Suatu hal tertentu; dan

4. Suatu sebab (causa) yang halal.

Berdasarkan kepada pengertian perjanjian serta syarat yang harus dipenuhi dalam perjanjian ada dua hal pokok yang dapat dikemukakan. Pertama, pada prinsipnya dalam hal penentuan isi perjanjian para pihak mempunyai kebebasan (asas kebebasan berkontrak) sepanjang tidak ada larangan. ${ }^{16}$

${ }^{12}$ Ibid.

13Munir Fuady. 1996. Hukum Perkreditan Kotemporer. Bandung: PT.Citra Aditya Bakti. Hlm. 21.

${ }^{14} B$ unyi selengkapnya dari Pasal 1313 KUHPerdata menyatakan suatu perjanjian adalah suatu perbuatan dengan mana satu orang atau lebih mengikatkan dirinya terhadap satu orang lain atau lebih. Lihat J. Satrio. 1995. Hukum Perikatan yang Lahir dari Perjanjian Buku I. Bandung: PT.Citra Aditya Bakti. HIm. 27. Lihat juga Mariam Darus Badrulzaman. 1994. Aneka Hukum Bisnis. Bandung: Alumni. Him. 18.

15. Satrio. Hukum Perikatan...Op.Cit. HIm. 27.

${ }^{16} \mathrm{Pasal} 1339$ KUHPerdata menentukan bahwa perjanjian yang dibuat tidak boleh bertentangan dengan undang-undang, kesusilaan, dan ketertiban umum. Artinya perjanjian tidak dapat dibuat sebebas-bebasnya tetapi ada batasannya. 
Kedua, untuk syarat-syarat perjanjian itu sendiri sifatnya mengikat bagi para.pihak.

Khusus berkenaan dengan prinsip kebebasan berkontrak dalam perkembangaannya dapat mendatangkan ketidakadilan. Alasannya prinsip ini baru dapat dicapai apabila kedudukan dan posisi para pihak dalam keadaan seimbang. Dengan kondisi demikian kecenderungan yang terjadi dalam dunia praktik bisnis pembuatan perjanjian tidak didasarkan pada prinsip kebebasan berkontrak dalam arti sepenuhnya. ${ }^{17}$ Kecenderungan yang ada salah satu pihak menyodorkan syaratsyarat baku dalam kontrak, kemudian pihak lain hanya diberi kebebasan untuk menerima atau menolak. Kontak seperti ini disebut dengan perjanjian baku atau perjanjian standar atau perjanjian adhesi atau standard contract.

Perjanjian baku adalah perjanjian yang hampir seluruh klausul-klausulnya sudah dibakukan oleh pemakainya dan pihak yang lain pada dasarnya tidak mempunyai peluang untuk merundingkan atau meminta perubahan. Selanjutnya dalam perjanjian baku ini yang dibakukan bukanlah formulimya, tetapi klausul-klausulnya. ${ }^{18}$ Menurut H.J. Sluyter yang dikutip H.P. Panggabean pengertian standard contract merupakan kontrak yang bersifat paksaan, bersifat lebih dipaksakan berdasarkan ketentuan ekonomi yang lebih kuat, sedang salah satu pihak di lain pihak kurang cukup pengertian tentang kontrak tersebut atau mungkin juga karena kecerobohan pada pihak lain. Dengan pengertian itu ia nampaknya mempersamakan standard contract itu dengan adhesie contract, di mana salah satu pihak di paksa oleh pihak lain. ${ }^{19}$

Mariam Darus Badurlzaman mengklasifikasikan standard contract ini ke dalam dua kelompok. Pertama, Perjanjian standar umum, artinya perjanjian yang bentuk dan isinya terlah dipersiapkan terlebih dahulu oleh kreditur kemudian disodorkan pada debitur. Kedua, perjanjian standar khusus, artinya perjanjian itu ditetapkan oleh pemerintah secara sepihak dan diberlakukan bagi para pitiak. ${ }^{20}$

UU Perbankan tidak menegaskan atau mengatur tentang bentuk perjanjian yang. harus dibuat oleh pihak bank dengan nasabahnya. Hal ini merupakan kebebasan kedua belah pihak untuk menentukan wujud perjanjian kredit yang dikehendaki. Perjanjian kredit yang dibuat oleh bank-bank dilakukan dengan dua bentuk atau cara; Pertama, perjanjian kredit berupa akta di bawah tangan; Kedua, perjanjian kredit berupa akta notaris. Perjanjian kredit yang dibuat baik dengan akta

- "Kebebasan berkontrak dalam arti sepenuhnya yang dimaksudkan penulis adalah bahwa sejak awal para pihak tidak tertibat langsung dalam pembuatan kontrak tersebut, terutama dalam menentukan materi maupun isi dari kontrak itu.

${ }^{18}$ Sutan Remy Sjahdeini.1993. Kebebasan Berkontrak dan Perlindungan yang Seimbang Bagi

Para Pihak dalam Perjanjian Kredit Bank di Indonesia. Jakarta: Institut Bankir Indonesia. HIm.66.

${ }^{19 H . P . P a n g g a b e a n . ~ " B e r b a g a i ~ M a s a l a h ~ Y u r i d i s ~ y a n g ~ D i h a d a p i ~ P e r b a n k a n ~ m e n g a m a n k a n ~ P e n g e m b a l i a n ~}$ Kredit yang Disalurkan." Majalah Varia Peradilan No. 80/1992.

20Mariam Darus Badrulzaman. 1978. Perjanjian Kredit Bank. Bandung: Alumni. HIm. 19. 
di bawah tangan maupun akata notaris, pada umumnya dibuat dengan bentuk perjanjian baku, yaitu pihak bank dan pihak nasabah, menandatangani suatu perjanjian yang sebelumnya, telah dipersiapkan isi atau kkausul-klausulnya oleh bank dalam suatu formulir tercetak. Dalam hal perjanjian kredit bank dibuat dengan akta notaris, maka bank akan meminta notaris berpodoman kepada model perjanjian kredit dari bank yang bersangkutan. Notaris diminta untuk memedomani klausul-klausul dari model perjanjian kredit bank yang bersangkutan. ${ }^{21}$

Dengan model; perjanjian baku berarti pihak debitur selaku pihak yang mengajukan permohonan kredit dalam bentuk perjanjian semacam itu tidak mempunyai position bergaining dalam menetapkan hal-hal yang akan disepakati. Dengan. demikian, penentuan syarat kesepakatan yang ada tergantung apakah debitur menyepakati klausul-klausul yang dibuat pihak bank atau tidak. Jikalau debitur menyepakati, maka hal ini dianggap telah terjadi kesepakatan antara pihak bank dengan debitur. Tetapi, sebaliknya apabila debitur tidak menyepakati klausulklausul tersebut, maka secara otomatis tidak terjadi kesepakatan tersebut dan perjanjian tidak terjadi.

- Sepintas selalu perjanjian kredit bank dalam format perjanjian baku terkesan pihak bank mempunyai bergaining power yang lebih kuat ketimbang pihak debitur. Praktiknya, pihak bank hanya mempunyai bergaining poweryang kuat hanya ketika pihak bank melakukan negosiasi kredit bank. Setelah perjanjian itu dilaksanakan, bank justru seringkali berada pada posisi yang lemah. Berdasarkan pada fakta ini tegaslah bahwa penerapan klausul baku dalam perjanjian kredit bank merupakan langkah preventif dari bank untuk mengamankan dana yang disalurkan kepada pihak debitur. Seperti diketahui bahwa dana yang disalurkan bank pada hakekatnya dana simpanan nasabah.

Penerapan klausul standar baku semakin realistis, tatkala bank sendiri dalam pembuatan perjanjian baku didasari pada asas iktikad baik. Iktikad baik tidak saja muncul di saat pelaksanaan dari perjanjian kredit bank. Iktikad baik harus sudah ada sejak hubungan kontraktual di mulai antara pihak bank dengan debitur. Atas dasar ini pihak bank tidak semena-mena dalam menentukan klausulklausul standar baku perjanjian kredit bank.

Beberapa contoh nyata klausul-klausul standar baku yang harus dihindari oleh pihak bank dalam perjanjian kredit bank, agar kepntingan debitur tidak dirugikan sebagaimana dikemukakan oleh Sutan Remy Sahdeini. Klausul-klausul itu meliputi:22

a. Kewenangan bank untuk sewaktu-waktu tanpa alasan apapun dan tanpa pemberitahuan sebelumnya secara sepihak menghentikan izin tarik kredit.

b. Bank berwenang secara sepihak menentukan harga jual dari barang agunan dalam hal penjualan barang agunan karena kredit nasabah debitur macet.

${ }^{21}$ Sutan Remy Sjahdeini. Op. Cit. HIm. 182.

${ }^{22}$ Jbid. HIm. 194-244. 
c: Kewajiban nasabah debitur untuk tunduk kepada segala petunjuk dan peraturan bank yang telah ada dan yang masih akan ditetapkan kemudian oleh bank.

d. Keharusan nasabah debitur untuk tunduk kepada syarat-syarat dan ketentuanketentuân umum hubungan rekening koran dari bank yang bersangkutan namun tanpa sebelúmnya nasabah debitur diberi kesempätan untuk mengetahui dan memahami syarat-syarat dan ketentuanketentuan umum hubungan rekeneing koran tersebut.

e. Kuasa nasabah debitur yang dapat dicabut kembali kepada bank untuk dapat melakukan segala tindakan yang dipandang perlu oleh bank.

f. Kuasa nasabah debitur kepada bank untuk mewakili dan melaksanakan hak-hak nasabah debitur dalam setiap rapat umum pemegang saham.

g. Pencantuman klausul-klausul eksemsi yang membebaskan bank dari tuntutan ganti kerugian oleh nasabah debitur atas terjadinya kerugian yang diderita olẹnnya sebagai akibat tindakan bank.

h. Pencantuman klausul eksemsi mengenai tidak adanya hak nasabah debitur untuk dapat menyatakan keberatan atas pembebanan bank terhadap rekeningnya.

i. Pembuktian kelalaian nasabah debitur secara sepihak oleh pihak bank semata.

j. Penetapan dan perhitungan bunga bank secara merugikan nasabah debitur.

Harapannya dengan diakomodirnya kepentingan bank maupun debitur, maka perjanjian kredit bank yang diformat dalam bentuk standard contract dapat memberikan keseimbangan baik bagi pihak bank maupun
: pihak debitur sendiri. Selain perjanjian kredit bank yang sudah dibakukan oleh pihak bank dapat diterima secara wajar.

\section{Simpulan}

Dalam praktik perjänjian kredit bank banyak mempergunakan bentuk standard contract. Hal ini dimaksudkan untuk menigamankan dana yang disalurkan kepada debitur. Oleh karena dana tersebut pada hakekatnya merupakan daná nasabah juga. Namun, di sisi lain bank mempunyai kewajiban untuk mempèrhatikan kepentingàn debitur. Sehingga "apabila hal ini "sudah dimplementasikan dalam perjanjian kredit bank, maka aspek keseimbangan dalam sebuah perjanjian dapat dipenuhi. $\square$

\section{Daftar Pustaka}

Badrulzaman, Mariam Darus. 1978. Perjanjian Kredit Bank. Bandung: Alumni.

\section{_-_, 1994. Aneka Hukum Bisnis. Bandung: Alumni.}

Fuady, Munir. 1996. Hukum Perkreditan Kotemporer. Bandung: PT.Citra Aditya Bakti.

Hadiwidjaja dan Rivai Wirasasmita. 1991. Analisis Kredit (Dilengkapi Telaah Khusus). Jakarta: Pionir Jaya.

Panggabean, H.P. "Berbagai Masalah Yưridis yang Dihadapi Perbankan mengamankan Pengembalian Kredit yang Disalurkan." Majalah Varia Peradilan No. 80/1992. 
Satrio, J. 1995. Hukum Perikatan yang Lahir dari Perjanjian Buku I. Bandung: PT.Citra Aditya Bakti:

Sinunga, Muchdarsah. 1983. Dasar-dasar dan Teknik Managemen.Kredit. Jakarta: Bina Aksara.

Sinưngan, Muchdarsah. 1992 Managemen Dana Bank. Jakarta: Bina Akșara. - :

Sjahdeini, Sutan Remy:1993. Këbebasan

Berkontrak dan Perlindungan yang Seimbang Bagi Para 'Pihak dalam Perjanjian Kredit Bank di Indonesia. ' Jakarta: Institut Bankir Indonesia.'
Supramono, Gatot. 1997. Perbankan dan Masalah Kredit (Suatu Tinjauan Yuridis). Jakarta: Djambatan.

Tjoekam, Moh.. 1999. Perkreditan Bisnis Inti Bank Komersial Konsep Teknik dan Kasus.Jakarta: Gramedia Pustaka Utama.

Widjanarto. "Kajian Legal dalam Analisa dan Proses Kredit Komersial serta Solusi Hukum - Menghadapi - Kredit Bermasalah." Dalam Solusi Hukum dalam Menyelesaikan Kredit Bermașalah. Jakarta: InfoBank:

Widjanairto. 1998. Aspèk Hukum Pemberian Kredit Perbankan. Jakarta: Info Bank. 